\title{
Hur bra har den svenska integrationskontexten varit på att främja balanserad tvåspråkighet?
}

\author{
Memet Aktürk Drake \\ Vikarierande universitetslektor \\ Centrum för tvåspråkighetsforskning \\ Institutionen för svenska och flerspråkighet \\ Stockholms Universitet \\ 10691 Stockholm \\ Affilierad forskare \\ Centre for Linguisitcs \\ Vrije Universiteit Brussel \\ memet.drake@gmail.com
}

\begin{abstract}
English
Keywords: balanced bilingualism, bilingual development, migration-related minorities, integration, Turks

This paper investigates how good the Swedish integration context has been at promoting balanced bilingualism among adult children of Turkish immigrants. Balanced bilingualism has been one of the goals of Sweden's multicultural language policy. An extensive comparison with corresponding groups in Rotterdam and Berlin is also presented. The data come from 430 participants in the project The Integration of the European Second Generation, of whom 133 resided in Stockholm. Balanced bilingualism is defined on the basis of the participants' selfassessed speaking and writing skills in Turkish and their respective second languages. The results show that only a minority of the second-generation Turks were balanced bilinguals in Stockholm, which constituted the lowest rate among the cities. At the same time, the Stockholm group displayed the highest skill levels in the second language among the three cities. The analysis points out that the inclusive multi-ethnic context in Stockholm had a positive effect on second-language skills, while the Turkish group's relatively small size and concentration coupled with the deficient implementation of mother-tongue instruction had a negative effect on Turkish skills. The other cities' more segregated and enclavelike integration contexts seem instead to better promote Turkish skills and thereby to lead to a higher occurrence of balanced bilingualism.
\end{abstract}


Nyckelord: balanserad tvåspråkighet, tvåspråkig utveckling, invandringsrelaterade minoriteter, integration, turkar

Den här artikeln undersöker hur bra den svenska integrationskontexten har varit på att främja balanserad tvåspråkighet hos vuxna barn till turkiska invandrare. Balanserad tvåspråkighet har nämligen varit ett av målen i Sveriges mångkulturella språkpolitik. Även ingående jämförelser med motsvarande grupper i Rotterdam och Berlin presenteras. Data kommer från 430 deltagare i projektet The Integration of the European Second Generation varav 133 bodde i Stockholm. Balanserad tvåspråkighet definieras utifrån deltagarnas självuppskattade tal- och skrivfärdigheter i förstaspråket turkiska och respektive andraspråk. Resultaten visar att bara en minoritet av andragenerationens turkar var balanserade tvåspråkiga i Stockholm, som dessutom utgjorde den lägsta andelen bland de undersökta städerna. Samtidigt uppvisade gruppen i Stockholm de högsta färdighetsnivåerna i andraspråket bland de tre städerna. Analysen pekar på att den inkluderande multietniska kontexten i Stockholm haft en positiv effekt på andraspråksfärdigheterna medan den turkiska gruppens relativt ringa storlek och koncentration tillsammans med den bristfälliga implementeringen av modersmålsundervisningen i Sverige haft en negativ effekt på turkiskfärdigheterna. De andra städernas mer segregerade och enklavliknande integrationskontexter verkar istället främja turkiskfärdigheterna mer och leder därmed även till en högre förekomst av balanserad tvåspråkighet. 


\section{Inledning}

Flera etniska minoritetsgrupper som har kommit till Sverige genom invandring firar nu 50 år i landet. Detta innebär att barnen till de första kohorterna av dessa invandrare är unga vuxna eller befinner sig i medelåldern idag. Det här halvseklet har inte bara bevittnat stora förändringar i Sveriges etnokulturella sammansättning utan även i integrationspolitiken gentemot invandringsrelaterade minoriteter. Sedan 1970-talet har en mångkulturell integrations- och språkpolitik med ett tvåspråkighetsfokus vuxit fram. Följaktligen har vi idag ett stort antal barn till invandrare som är födda och uppvuxna i Sverige under denna politik. Således befinner vi oss i en fördelaktig demografisk situation för att undersöka de långsiktiga effekterna av den svenska integrationskontexten på tvåspråkighet.

Ett av de uttalade målen i Sveriges mångkulturella språkpolitik har varit att främja balanserad tvåspråkighet (kallad "aktiv tvåspråkighet" i styrdokumenten) hos barn till invandrare. Syftet med denna artikel är att undersöka hur bra den svenska integrationskontexten har varit på att främja balanserad tvåspråkighet hos barn till invandrare utifrån ett jämförande västeuropeiskt perspektiv. Data kommer från det stora europeiska integrationsprojektet The Integration of the European Second Generation. För detta ändamål kommer det först att redogöras för den svenska integrationskontexten gällande den turkiska gruppen ur ett västeuropeiskt perspektiv samt för synen på balanserad tvåspråkighet i de ursprungliga integrations- och språkpolitiska styrdokumenten. Sedan kommer det att undersökas i vilken mån målet har uppnåtts med hjälp av ett representativt urval av barn till turkiska invandrare $\mathrm{i}$ Stockholm. Till sist kommer även en jämförelse att presenteras för motsvarande grupper i Rotterdam och Berlin.

\section{Integrationskontexten}

Integrationskontexten betraktas här som den sociala kontext där invandringsrelaterade minoriteters införlivande i samhällets institutioner och sociala strukturer sker, och som påverkas både av faktorer på makronivå och gruppnivå (efter Schneider \& Crul, 2012, s. 29-33). På makronivå innehåller integrationskontexten den migrationsmottagande statens ideologi gentemot etnokulturell mångfald och minoriteter, regeringars invandrings- och integrationspolitik samt majoritetssamhällets attityder gentemot invandringsrelaterade minoriteter. På gruppnivå består integrationskontexten av specifika invandringsrelaterade minoriteters egna egenskaper som t.ex. deras storlek och geografiska spridning, inbördes struktur och relationer samt deras attityder till och relationer med majoritetssamhället och dess institutioner. I analysen av en specifik invandringsrelaterad minoritets integrationsmönster spelar därmed både integrationskontextens makrofaktorer och faktorer på gruppnivå viktiga roller (Bourhis m.fl., 1997). Eftersom gruppmedlemmarnas tvåspråkiga profiler (inkl. deras språkbehärskning) också utgör en del av gruppens allmänna integrationsmönster påverkar integrationskontexten även minoritetsgruppens tvåspråkighet (jfr "den sociala kontextens" roll i Spolskys (1989) modell över andraspråksinlärning). Följaktligen är huvudantagandet bakom den här studien att skillnader i tvåspråkiga profiler, mer specifikt skillnader i förekomsten av balanserade färdigheter i bägge språken, kommer att hittas när en invandringsrelaterad grupp med samma bakgrund jämförs i tre olika västeuropeiska integrationskontexter.

\section{Den svenska integrationskontexten ur ett västeuropeiskt makroperspektiv}

För att kartlägga hur integrationskontexten i Sverige förhåller sig till andra länder i Europa gjordes en sökning i forskningsdatabaser efter internationella studier som med samma metodologi undersökt och jämfört invandrares integration, attityder till invandrare och integrationspolitiken i ett stort antal europeiska länder inklusive Sverige. De mest relevanta 
frågorna och variablerna i sådana undersökningar valdes sedan ut för denna artikel och redovisas i Tabell 1.

Tabell 1 Inkludering av invandrare och deras barn i den svenska integrationskontexten jämfört med andra europeiska länder

\begin{tabular}{|c|c|c|c|c|}
\hline & & Sverige & Nederländerna & Tyskland \\
\hline 1 & $\begin{array}{l}\text { Kumulativt totalbetyg i procent 1980-2010 } \\
\text { på Multiculturalism Policy Index (2017) } \\
\text { bland } 16 \text { länder }\end{array}$ & $\begin{array}{l}58 \\
\text { högst }\end{array}$ & $\begin{array}{l}36 \\
3: \text { e högst }\end{array}$ & $\begin{array}{l}16 \\
10: e \\
\text { högst }\end{array}$ \\
\hline 2 & $\begin{array}{l}\text { Kumulativt betyg i procent } 1980-2010 \text { ang. offentligt } \\
\text { finansierat stöd för tvåspråkighet }{ }^{1} \text { inom } \\
\text { utbildningsväsendet på Multiculturalism Policy Index } \\
\text { (2017) bland } 16 \text { länder }\end{array}$ & $\begin{array}{l}100 \\
\text { högst }\end{array}$ & $\begin{array}{l}50 \\
3: e \text { högst }\end{array}$ & $\begin{array}{l}37,5 \\
6: e \text { högst }\end{array}$ \\
\hline 3 & $\begin{array}{l}\text { Senaste totalbetyget i procent } 2010 \text { på Multiculturalism } \\
\text { Policy Index (2017) bland } 16 \text { länder }\end{array}$ & $\begin{array}{l}87,5 \\
\text { högst }\end{array}$ & $\begin{array}{l}25 \\
8: e \text { högst }\end{array}$ & $\begin{array}{l}\text { 31,3 } \\
7: e \text { högst }\end{array}$ \\
\hline 4 & $\begin{array}{l}\text { Procentandel som inte vill ha grannar som är invandrare } \\
\text { eller utländsk arbetskraft enligt World Values Survey } \\
\text { 2005-2009 bland } 21 \text { länder }\end{array}$ & $\begin{array}{l}1,8 \\
\text { lägst } \\
\text { (lägst även } \\
\text { 1995-1999) }\end{array}$ & $\begin{array}{l}8,9 \\
6: e \text { lägst }\end{array}$ & $\begin{array}{l}13,3 \\
7: e \text { lägst }\end{array}$ \\
\hline 5 & $\begin{array}{l}\text { Procentandel som inte vill ha grannar som talar ett annat } \\
\text { språk enligt World Values Survey 2005-2009 bland } 21 \\
\text { länder }\end{array}$ & $\begin{array}{l}1,2 \\
\text { lägst }\end{array}$ & $\begin{array}{l}9,7 \\
\text { 13:e lägst }\end{array}$ & $\begin{array}{l}\text { 8,7 } \\
9: e \text { lägst }\end{array}$ \\
\hline 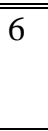 & $\begin{array}{l}\text { Procentandel som ser positivt på invandrarnas effekt på } \\
\text { samhället i Special Eurobarometer } 469 \text { (TNS Opinion } \\
\text { \& Social, 2018, s. 72) bland } 28 \text { länder }\end{array}$ & $\begin{array}{l}76 \\
\text { högst }\end{array}$ & $\begin{array}{l}58 \\
4: e \text { högst }\end{array}$ & $\begin{array}{l}44 \\
11: e \\
\text { högst }\end{array}$ \\
\hline 7 & $\begin{array}{l}\text { Betyg i procent på Migrant Integration Policy Index } \\
\text { (Huddleston m.fl., 2014) bland } 32 \text { länder }\end{array}$ & $\begin{array}{l}78 \\
\text { högst } \\
\end{array}$ & $\begin{array}{l}60 \\
6: \text { e högst }\end{array}$ & $\begin{array}{l}61 \\
7: e \text { högst }\end{array}$ \\
\hline 8 & $\begin{array}{l}\text { Jämlikhet mellan inrikes födda unga vuxna med inrikes } \\
\text { respektive utrikes födda föräldrar gällande andelen högt } \\
\text { utbildade personer (OECD,2015, s. 247) bland } 12 \\
\text { länder }\end{array}$ & 2:a störst & 4:e störst & minst \\
\hline 9 & $\begin{array}{l}\text { Jämlikhet mellan inrikes födda unga vuxna med inrikes } \\
\text { respektive utrikes födda föräldrar gällande andelen } \\
\text { arbetslösa (OECD, 2015, s. 298) bland } 12 \text { länder }\end{array}$ & 5:e störst & 6:e störst & 9:e störst \\
\hline 10 & $\begin{array}{l}\text { Summerande rangordning av integrationskontextens } \\
\text { grad av inkludering }\end{array}$ & 1 & 2 & 3 \\
\hline
\end{tabular}

Raderna 1-3 i Tabell 1 visar några utvalda uppgifter från Multiculturalism Policy Index (2017). Detta index baseras på bedömningar av policydokument utifrån 8 olika parametrar och har gjorts i fyra omgångar sedan 1980. Enligt resultaten har Sverige fört både den totalt sett mest mångkulturellt orienterade politiken mot invandringsrelaterade minoriteter och gett det största offentliga stödet till tvåspråkighet inom utbildningsväsendet i Europa under perioden 1980-2010. Raderna 4-5 presenterar resultat från World Values Survey (2017) som är en internationell enkätundersökning om olika värderingar bland ett stort representativt urval ur allmänheten i ett stort antal länder sedan 1980-talet. En av frågetyperna i enkäten innebär att deltagarna utifrån en specificerad lista ska ange olika grupper som de inte skulle vilja ha som grannar. De presenterade siffrorna gäller procentandelen bland deltagare som uttryckt negativa attityder mot invandrare och talare av andra språk. Resultaten visar att de mest positiva attityderna gentemot etnokulturell mångfald i Europa fanns i Sverige. På rad 6 redovisas uppgifter från Special Eurobarometer 469 (TNS Opinion \& Social, 2018) som är en stor enkätundersökning om invandrares integration i EU som genomförts på uppdrag av Europeiska Kommissionen. Deltagarna i varje land fick bl.a. svara på 7 frågor om hur de ser på invandrarnas effekt på samhället (TNS Opinion \& Social, 2018, s. 68-79). Sammanvägningen av dessa svar i undersökningen (TNS Opinion \& Social, 2018, s. 72) visar att andelen med 
positiv syn var högst i Sverige. På rad 7 presenteras resultat från Migrant Integration Policy Index (Huddleston m.fl., 2014). Detta index mäter utifrån en rad olika parametrar i vilken mån olika länders integrationspolitik ger invandrare samma rättigheter och möjligheter som den inhemska befolkningen. Här fick Sverige det högsta betyget vilket kan tolkas som att Sverige har den mest inkluderande integrationspolitiken i Europa. Andra uppgifter visar dessutom att denna ambition för inkludering även omsatts i verkligheten bland barn till invandrare i Sverige. Resultaten från OECD:s senaste integrationsrapport på raderna 8-9 visar att Sverige är näst bäst i Europa på att främja jämlikhet vad gäller utbildning och femte bäst vad gäller jämlik arbetslöshetsgrad mellan unga vuxna med inhemsk respektive utländsk bakgrund.

Även resultaten för Nederländerna och Tyskland presenteras i Tabell 1. Jämförelsen visar att Sverige skiljer sig markant från dessa länder. Nederländerna, som liksom Sverige hade en mångkulturell politik fram till 1990-talet, har senare skiftat till en assimilationistisk politik (jämför raderna 3 och 1). Tysklands politik innehöll såväl assimilationistiska som segregationistiska inslag fram till 1990-talet (Bourhis m.fl., 1997) men har börjat uppvisa mångkulturella inslag sedan dess (jämför raderna 3 och 1). Dessutom hade Sverige en aktiv integrationspolitik gentemot arbetskraftsinvandrare, där de inte betraktades som gästarbetare som förväntades återvända till sina hemländer till skillnad från politiken i många andra västeuropeiska länder, inklusive Tyskland och Nederländerna (Bengtsson \& Borevi, 2015, s. 17). Därmed kan man konstatera i denna jämförelse länderna emellan att Sverige har utgjort den mest inkluderande integrationskontexten utifrån den förda politiken och dess påverkan på såväl invandringsrelaterade minoriteter som på allmänhetens syn på dem. Sverige följs efter ett tydligt glapp av Nederländerna och sedan av Tyskland. Denna övergripande rangordning utifrån samtliga data i Tabell 1 återges på rad 10 .

\section{Sveriges mångkulturella språkpolitik gentemot barn till invandrare}

Sverige anses ha infört mångkulturalismen officiellt i mitten på 1970-talet genom integrationsreformen med de väl kända slagorden "jämlikhet, valfrihet, samverkan" (Prop. 1975:26) och hemspråksreformen (Prop. 1975/76, s. 118). Formuleringen "aktiv tvåspråkighet" förekommer i utdragen U1 och U2 och tolkas här med hjälp av utdrag U3 som balanserad tvåspråkighet (se även Hyltenstam \& Tuomela 1996, s. 100 för en liknande tolkning). Fortsättningsvis kommer balanserad tvåspråkighet att operationaliseras som lika goda färdigheter på en hög behärskningsnivå i första- och andraspråket.

U1: "Mot bakgrund av forskningsrön om språkutveckling och tvåspråkighet anser [Invandrarutredningen] att målet med utbildningen av invandrarbarn bör vara att främja aktiv tvåspråkighet." (Prop. 1975:26, s. 20)

U2: "[Hemspråksundervisningen] skall ge grunden för elevens utveckling mot aktiv tvåspråkighet. [...] Eleverna skall lära sig lyssna och tala, läsa och skriva och därvid få tillit till sin egen förmåga att använda språket. [...] Undervisningen skall bidra till att eleverna klarar av den språkliga och kulturella påfrestning som kan ligga i att tillhöra en minoritetsgrupp." (Lgr 80, s.145-146, Kursplanen för hemspråk)

U3: "För invandrarbarnen däremot är inlärningssituationen och målsättningen en helt annan än för de svenska barnen. De skall uppnå vad man kallar förstaspråksnivå i båda språken. [...] För att invandrareleverna skall kunna nå förstaspråksnivå i sina egna språk krävs ännu mera undervisning i hemspråken eftersom språkstimulansen i Sverige är otillräcklig för invandrarbarnen." (SOU 1983:57, s. 143)

De instrument som utsågs i 1970-talets styrdokument för att främja balanserad tvåspråkighet hos barn till invandrare var särskild undervisning i svenska, modersmålsundervisning ${ }^{2}$ och 
ämnesundervisning på modersmålet. Hyltenstam \& Milanis (2012, s. 78-82) genomgång av implementeringen av ämnet svenska som andraspråk (sva) pekar dock på låg status för ämnet och på allvarliga brister av olika slag. Enligt uppgifter från Skolverket (2017) läste i genomsnitt 54 procent av alla elever som var berättigade till modersmålsundervisning sva i grundskolan på 1990-talet ${ }^{3}$. Hyltenstam \& Milanis (2012, s. 65-71) genomgång av olika studier och rapporter om modersmålsundervisningens implementering pekar på ännu allvarligare brister i modersmålsundervisningen än för sva. Sedan förändringarna och nedskärningarna på 1990talet kan man tala om en verksamhet på existensminimum, ofta med bara 45 minuters undervisning per vecka. Enligt uppgifter från Skolverket (2017) är den allmänna trenden sedan 1990-talet att drygt hälften av de berättigade eleverna i grundskolan och betydligt mindre än hälften på gymnasiet deltar i modersmålsundervisning. Flera studier har dock visat att t.o.m. denna begränsade modersmålsundervisning i grundskolor och på gymnasier gynnar både litteraciteten i modersmålet (Nygren-Junkin, 2004; Bylund \& Díaz, 2012; Ganuza \& Hedman, 2017) och den allmänna behärskningen av modersmålet (Bylund \& Díaz, 2012).

Enligt Multiculturalism Policy Index (2017) har det funnits stora skillnader sedan 1980 mellan Sveriges, Nederländernas och Tysklands nivå av offentligt finansierat stöd för tvåspråkighet (se rad $2 \mathrm{i}$ Tabell 1). Som beskrivningen av implementeringen ovan illustrerat har dock praktiken i Sverige inte kunnat leva upp till ambitionsnivån i policydokumenten och det är just ambitionsnivån som mäts av indexet. Utöver sina egna initiativ till modersmålsundervisning i mindre offentligt sanktionerade former jämfört med Sverige, har de två andra länderna i olika utsträckning tillåtit en "outsourcing" av modersmålsundervisningen till ursprungsländer som ingått avtal med dem. Turkiet är ett av de länder som skickat lärare till Tyskland samt efter 2000 även till Nederländerna. Trots dessa skillnader på policynivå verkar undervisningen i turkiska i dessa länder i praktiken ha skett i relativt liknande former som i Sverige (Schmitt \& Oomen-Welke, 2005; Yağmur 2016).

\section{Den turkiska gruppen i Sverige och i övriga diasporakontexten}

Den turkiska gruppen har valts ut som testfall här p.g.a. gruppens numerära styrka och geografiska koncentration i storstäderna. Tack vare dessa omständigheter har turkar nämligen kunnat ta del av Sveriges mångkulturella språkpolitik från början som en tidigt invandrad grupp och i större utsträckning än många andra invandrargrupper. Sedan 1960-talet har det skett en omfattande utvandring från Turkiet till Västvärlden som huvudsakligen bestått av lågutbildade personer från landsbygden. Etniska turkar kom till Sverige huvudsakligen genom arbetskraftsoch anhöriginvandring efter mitten av 1960-talet och antalet personer med etniskt turkiskt ursprung uppskattas idag ligga kring 60000 varav ungefär hälften bor i Stockholms län (Aktürk-Drake, 2017). Från sena 1970-talet till 2015 var turkiska bland de tio största modersmålen i grundskolan (Skolverket, 2017). Den turkiska invandringen till de övriga västeuropeiska länderna liknar i stort sett den till Sverige med den stora skillnaden att turkar utgör den numerärt viktigaste invandrargruppen i både Nederländerna och Tyskland, inklusive jämförelsestäderna Rotterdam med 47000 (Beets m.fl., 2008, 34) och Berlin med 177000 (Statistischer Bericht, 2017) personer med bakgrund i Turkiet.

Under det senaste decenniet har barn till turkiska invandrare ingått i flera internationella studier om ackulturation och språkliga förhållanden inom diasporagrupper i Västvärlden. Dessa studier har konstaterat att turkar är en starkt arvsorienterad grupp där det turkiska språket utgör en central markör för familjens kulturella arv och identitet (Yağmur, 2016). I Västeuropa är det vanligaste mönstret att andragenerationens turkar identifierar sig svagt med majoritetssamhället men starkt som turkar samt bevarar sin turkiska i hög utsträckning (Yağmur, 2016). Eftersom det motsatta mönstret har iakttagits bland turkar i Australien och USA anses turkiskans bevarande uppvisa en tydlig känslighet för integrationskontexten 
(Pauwels, 2016, s. 100), vilket gör den turkiska gruppen särskilt lämplig för att testa integrationskontextens effekter.

Officiella uppgifter om modersmålsundervisningen i turkiska inom grundskolan i Stockholms län visar att deltagandet bland alla berättigade elever har varierat mellan 60 och 90 procent under perioden 1978-2008. ${ }^{4}$ Mer detaljerade uppgifter från Statistiska centralbyrån (2017) gällande Stockholms län under perioden 1997-2006 visar att deltagandet legat mellan 60 och 70 procent för turkiskundervisningen och strax över 70 procent för undervisningen i sva. Deltagandet i turkiskundervisningen motsvarar därmed det relativt höga genomsnittet för samtliga minoritetsspråk i länet medan deltagandet i sva ligger tydligt över länsgenomsnittet. Dessa uppgifter visar att den turkiska gruppen har exponerats för Sveriges mångkulturella språkpolitiks olika åtgärder i mycket hög grad.

\section{Tidigare forskning om faktorer som påverkar färdighetsutveckling hos tvåspråkiga minoriteter}

Undersökningsobjektet $\mathrm{i}$ den här artikeln är hur successivt tvåspråkiga själva bedömer relationen mellan sina språk utifrån sina behärskningsnivåer i dem. Därför är det angeläget att redogöra för de faktorer som påverkar behärskningsnivån i första- och andraspråk hos tvåspråkiga samt för de makrofaktorer i integrationskontexten som ramar in dem.

Flera studier har visat att successivt tvåspråkiga som har haft en enspråkig eller förstaspråksdominant period före andraspråksinlärningens start uppvisar bättre färdigheter i förstaspråket jämfört med simultant tvåspråkiga, dvs. de som lärt sig sina två språk parallellt från början (se Montrul 2016, s. 113 för en översikt). Således kan en tidig start i en majoritetsförskola före treårsåldern innebära långsiktiga nackdelar för tvåspråkiga barns förstaspråksbehärskning. Stödet för arvspråket ${ }^{5}$ i skolan spelar också en avgörande roll därför att många grammatiska, pragmatiska och sociolingvistiska färdigheter som ingår i vuxnas modersmålskompetens, inte minst litteraciteten, utvecklas med hjälp av den pedagogik och diversifierade språkanvändning som är typiskt förekommande i skolan och som kräver substantiellt inflöde under minst 13 till 14 levnadsår (Montrul, 2016, s. 117-119). När stödet för arvspråk är obefintligt eller svagt blir därmed förstaspråksinflödets mängd och diversifiering otillräcklig för att minoritetsbarn och -ungdomar ska kunna bemästra de grammatiska strukturer som de har lärt sig (Montrul, 2016, 118). En sådan "inlärning utan bemästrande" (Montrul, 2016) kan leda till grammatisk osäkerhet i vuxen ålder, vilket i sin tur kan leda till sämre självförtroende i förstaspråksfärdigheter.

Vidare är språkbehärskningen även en viktig del i invandringsrelaterade minoritetsspråks bevarande över flera generationer. Flera forskningsöversikter över makrofaktorer som gynnar språkbevarande (Hyltenstam m.fl., 1999, s. 54-62, 82-88; Pauwels, 2016, s. 101-113) tar bl.a. upp faktorer relaterade till vad som motsvarar integrationskontexten i denna artikel. Dessa översikter pekar på att minoritetsgruppens sociala, kulturella och i synnerhet språkliga segregation samt egna kulturinstitutioner (inkl. skolor) har en genomgående gynnande effekt på bevarandet av minoritetsspråk. Även andra faktorer, som minoritetsgruppens storlek, kulturella olikhet till majoritetssamhället och värdering av sitt arvspråk som identitetsmarkör samt majoritetens positiva attityder gentemot minoriteten (inkl. integrations- och språkpolitik), har visat sig gynna bevarandet av minoritetsspråk i vissa kontexter.

Vad gäller andraspråksutvecklingen har tidigare forskning visat att den slutliga behärskningsnivån i ett andraspråk mest beror på språkbegåvning, motivation och startålder för inlärningen (Dörnyei \& Skehan, 2003), medan vissa studier också pekat på inflödets kvantitet som ytterligare en viktig faktor (Derwing, 2008). Språkbegåvning är normalt fördelad i större populationer och spelar en försumbar roll hos tidiga inlärare (Abrahamson \& Hyltenstam, 2008), varför den inte anses utgöra en avgörande faktor i den aktuella undersökningen. Startåldern för andraspråksinlärningen kan i denna studie överlappa startåldern för offentlig 
utbildning för de deltagare som började i förskolan mycket tidigt och därmed hade sin första väsentliga exponering för andraspråket i förskolan.

Integrationskontextens påverkan på språkinlärningen hos olika etniska grupper samt effekten av relationen mellan majoriteteten och andraspråksinlärare som minoritetsmedlemmar fick större uppmärksamhet i tidiga strukturalistiskt orienterade sociolingvistiska studier. Gardner \& Lambert (1972) fann att integrativ motivation, dvs. motivationen att lära sig andraspråket för att bli en del av samhället, bidrog till högre behärskningsnivåer i andraspråket. Lambert (1974) hävdade vidare att additiv tvåspråkighet uppnåddes i sociala kontexter där talare hade positiva attityder till både den egna minoritetskulturen och majoritetskulturen, vilket i sin tur var en viktig förutsättning för balanserad tvåspråkighet. Enligt Spolskys (1989) modell över andraspråksinlärning skapar den sociala kontexten å ena sidan själva inlärningsmöjligheterna och leder å andra sidan även till attityder hos inläraren. Attityderna yttrar sig som motivation hos inläraren, som i sin tur påverkar hur väl denne utnyttjar de skapade inlärningsmöjligheterna. Dessa faktorer relaterade till den sociala kontexten avgör tillsammans hur bra inläraren till slut behärskar sitt andraspråk.

\section{Metod}

De data som kommer att diskuteras i denna artikel har hämtats från det stora europeiska forskningsprojektet The Integration of the European Second Generation (Crul m.fl., 2012; Westin, 2015), hädanefter kallat TIES. Projektets syfte var att undersöka olika länders och städers påverkan på integrationen hos barn till invandrare som vid undersökningens tidpunkt befann sig mellan åldrarna 18 och 35. Datainsamlingen genomfördes mellan åren 2006 och 2008 med barn till invandrare från tre olika länder. Barnen var födda och uppvuxna i 15 städer i 8 olika länder i Västeuropa. Gruppen med bakgrund i Turkiet, som innehöll olika etniciteter, hade den bredaste spridningen med 7 länder och 13 städer varav Stockholm var en.

I Stockholm fick Statistiska centralbyrån uppdraget att göra ett slumpmässigt urval ur Registret över totalbefolkningen. Detta resulterade i ett urval bestående av 251 inrikes födda personer bosatta i Stockholms län och vars föräldrar var födda i Turkiet (se Westin, 2015 för en utförligare beskrivning). Utifrån frågor om deras föräldrars etnicitet gjordes för denna artikel ett andra urval med 133 personer som angett att båda deras föräldrar var etniska turkar uppvuxna i Turkiet, dvs. bodde där minst fram till 15-årsåldern. I de andra två länderna hade två städer vardera ingått i undersökningen och staden med landets största turkiska grupp valdes ut för denna undersökning. Även i dessa städer rekryterades omkring 250 deltagare per stad fast inte genom slumpmässigt urval utan genom andra metoder för att säkerställda en hög grad av representativitet för barn till invandrare från Turkiet (se Groenewold \& Lessard-Phillips, 2012, s. 43-44, 50). Ett andra urval av deltagare med etnisk turkisk bakgrund i Rotterdam och Berlin gjordes för denna artikel, dels genom att välja deltagare vars föräldrar bott i Turkiet minst fram till 15-årsåldern och dels genom att identifiera deltagare som inte rapporterade någon användning av minoritetsspråk från Turkiet inom familjen. Detta urval ledde till 182 personer i Rotterdam och 115 personer i Berlin. Hädanefter kommer denna grupp vara i fokus och refereras till som andragenerationens turkar. I samtliga städer var ungefär 40 procent av deltagarna 70-talister medan 60 procent var 80-talister.

Deltagarna besvarade under en muntlig intervju omfattande enkätfrågor om sina föräldrars bakgrund och om sig själva avseende olika teman utifrån utförliga skriftliga underlag. Dessa teman inkluderade utbildning, sysselsättning, inkomst, boende, sociala relationer (inkl. parförhållanden), religion och identitet. Bland flera aspekter som undersöktes under temat identitet ingick även språkrelaterade frågor. Detta fåtal frågor riktade sig å ena sidan mot språkanvändning med olika närstående personer samt föräldrarnas språkanvändning under deras uppväxt. Å andra sidan ombads deltagarna att uppskatta sina färdigheter i olika språk (majoritetsspråket och ett eller flera minoritetsspråk från föräldrarnas hemland). Här bör 
det påpekas att ingen lingvist har medverkat i projektets och enkätfrågornas förberedande. Artikelförfattaren blev involverad i projektet som enda lingvist först efter att resultaten blivit publicerade.

Språkfrågorna i enkäten kan därmed sägas tjäna två huvudsakliga syften, dels att identifiera etnisk bakgrund (i synnerhet vad gäller föräldrarna) och dels att utgöra ytterligare ett mått på deltagarnas integration i majoritetssamhället och på deras etnokulturella orientering i minoritetskontexten. Således kan synen på språk i detta kvantitativt inriktade samhällsvetenskapliga forskningsprojekt beskrivas som något som huvudsakligen återspeglar andra bakgrundsförhållanden. Dessutom hade det dessvärre heller inte samlats uppgifter om deltagande $\mathrm{i}$ andraspråksundervisning eller undervisning $\mathrm{i}$ eller på modersmålet samt dess omfattning och upplägg. Språkfärdighetsfrågorna följde en koncis och konventionell mall och riktade in sig på tre typer av självuppskattade färdigheter: tala, läsa, skriva. Frågorna var formulerade som "Hur bra tycker du att din turkiska respektive ditt andraspråk är när det gäller att tala/läsa/skriva?" Svarsalternativen på den sexgradiga skalan var "utmärkt", "mycket bra", "bra", "inte så bra", "dålig" och "inte bra alls".

Som framgår av beskrivningen ovan innebär frånvaron av lingvister i projektets planering och utförande uppenbarliga begränsningar vad gäller kvantiteten och kvaliteten på språkfrågorna i enkätundersökningen. Därmed är det inte möjligt att fånga in deltagarnas tvåspråkighet och förhållandet mellan deras två språk på ett uttömmande sätt. Däremot har TIES-projektets material två viktiga styrkor som ändå gör det intressant och lämpligt för den aktuella undersökningen. För det första är deltagarantalet stort och deltagarprofilen håller en hög grad av representativitet. För det andra ger hela projektets resultat en gedigen överblick över de integrationsmässiga förhållandena för barn till invandrare från Turkiet i stora delar av Västeuropa. Således erbjuder materialet en utmärkt möjlighet att kontextualisera förhållandena för andra generationens turkar i Stockholm och jämföra dem med andra integrationskontexter i Västeuropa.

\section{Analys}

Eftersom såväl språkvariablerna som ett flertal av bakgrundsvariablerna som kommer att diskuteras i den här undersökningen mäts på en ordinalskala och inte är normalfördelade har icke-parametriska metoder använts i de statistiska analyserna. För att undersöka om det fanns statistiskt signifikanta skillnader i olika avseenden mellan deltagargrupperna i de tre olika städerna användes Mann-Whitney U-tester. Närmare jämfördes Stockholmsgruppen parvis med grupperna i Rotterdam respektive Berlin. I vissa fall redovisas även jämförelser mellan Rotterdam och Berlin. Eftersom det görs många parvisa jämförelser mellan de tre städerna tillämpas här det lägre signifikansvärdet 0,01 (1 procent) i Mann-Whitney U-testerna.

Vidare undersöktes hur stora de signifikanta skillnaderna var genom en separat beräkning av den så kallade effektstorleken. Effektstorleken beräknades här enligt formeln Effektstorlek $(\mathrm{ES})=\mathrm{Z} / \sqrt{\mathrm{N}}$ dvs. Z-värdet från Mann-Whitney U-testet dividerat med roten av de respektive jämförelsegruppernas sammanlagda deltagarantal. Enligt gängse praxis i statistisk litteratur betraktas en effektstorlek under 0,3 som liten, en effektstorlek mellan 0,3 och 0,5 som medelstor och en effektstorlek över 0,5 som stor. Vid ett tillfälle, nämligen när de olika språkfärdigheterna hos talarna jämfördes med varandra, användes istället Wilcoxon Signed Rank-testet eftersom värdena som jämförs i sådana fall inte är oberoende utan snarare utgör mätningar av en och samma individ under två olika villkor. 


\section{Resultat och diskussion}

Kontextualisering av Stockholm utifrån deltagarnas bakgrund och integrationsmönster Tabellerna 2 och 3 sammanfattar grundläggande information om de tre länderna och städerna samt deltagarnas integrationsprofiler med utgångspunkt i de faktorer som tidigare forskning har funnit relevanta för första- och andraspråksbehärskning hos tvåspråkiga. Tabell 3 presenterar resultatet av de statistiska jämförelserna mellan städerna utifrån samtliga svarsalternativ i varje variabel och tjänar som komplement till Tabell 2. Tabell 2 fokuserar istället på särskilda svarsalternativ eller grupperingar av svarsalternativ för att illustrera integrationsrelaterade skillnader mellan andragenerationens turkar i de tre städerna.

Tabell 2. Översikt över undersökningens deltagare i tre västeuropeiska städer (Källa: TIES-projektet)

\begin{tabular}{|c|c|c|c|c|}
\hline & & Stockholm & Rotterdam & Berlin \\
\hline & Deltagarantal i denna undersökning & 133 & 182 & 115 \\
\hline 1 & $\begin{array}{l}\text { Deltagare med minst en förälder som har } \\
\text { gymnasieexamen eller högre utbildning }\end{array}$ & $69,9 \%$ & $49,1 \%$ & $18,7 \%$ \\
\hline \multicolumn{5}{|c|}{ INSTITUTIONELL INTEGRATION: Medborgarskap, utbildning och sysselsättning } \\
\hline 2 & Medborgare i undersökningslandet & $97,7 \%$ & $96,2 \%$ & $88,7 \%$ \\
\hline 3 & $\begin{array}{l}\text { Start i offentlig utbildning } \\
\text { före 3-årsåldern }\end{array}$ & $47,3 \%$ & $4,9 \%$ & $0 \%$ \\
\hline 4 & Högskoleexamen & $27,8 \%$ & $27,5 \%$ & $3,5 \%$ \\
\hline 5 & $\begin{array}{l}\text { Sysselsatt med utbildning, arbete, praktik } \\
\text { mm. }\end{array}$ & $88,7 \%$ & $77,3 \%$ & $55,7 \%$ \\
\hline \multicolumn{5}{|c|}{ SOCIAL INTEGRATION/SEGREGATION I: Relationen till majoritetssamhället } \\
\hline & $\begin{array}{l}\text { Inga eller mycket få vänner med } \\
\text { majoritetsbakgrund under gymnasietiden }\end{array}$ & $31,2 \%$ & $45,8 \%$ & $65,2 \%$ \\
\hline 7 & $\begin{array}{l}\text { Inga eller mycket få vänner med } \\
\text { majoritetsbakgrund nu }\end{array}$ & $34,1 \%$ & $43,4 \%$ & $63,5 \%$ \\
\hline 8 & $\begin{array}{l}\text { Stark eller mycket stark tillhörighet till } \\
\text { staden }\end{array}$ & $69,7 \%$ & $62,8 \%$ & $47,9 \%$ \\
\hline \multicolumn{5}{|c|}{ SOCIAL INTEGRATION/SEGREGATION II: Relationen till den egna etniska gruppen } \\
\hline 9 & $\begin{array}{l}\text { Minst hälften av invånarna } \\
\text { bostadsområdet har turkisk bakgrund }\end{array}$ & $21 \%$ & $33,7 \%$ & $60,6 \%$ \\
\hline 10 & $\begin{array}{l}\text { Majoriteten av de närmaste vännerna } \\
\text { under skoltiden hade turkisk bakgrund }\end{array}$ & $37,3 \%$ & $61,1 \%$ & $77,4 \%$ \\
\hline 11 & $\begin{array}{l}\text { Majoriteten av de närmaste vännerna nu } \\
\text { har turkisk bakgrund }\end{array}$ & $46,7 \%$ & $69,5 \%$ & $74 \%$ \\
\hline & Partner med turkisk bakgrund & $81,8 \%$ & $91,4 \%$ & $85,7 \%$ \\
\hline & $\begin{array}{l}\text { Stark eller mycket stark turkisk } \\
\text { tillhörighet }\end{array}$ & $69,9 \%$ & $83,7 \%$ & $75,6 \%$ \\
\hline 14 & Turkars ungefärliga antal i staden & 30000 & 47000 & $177000 *$ \\
\hline & $\begin{array}{l}\text { Turkars ungefärliga andel i stadens } \\
\text { befolkning }\end{array}$ & $1,3 \%$ & $8 \%$ & $5 \%$ \\
\hline
\end{tabular}

Förutom de data som presenteras i dessa tabeller har även olika variabler om deltagarnas bakgrund, i synnerhet om deras föräldrars bakgrund, undersökts med hjälp av samma statistiska metoder som i Tabell 3. Det fanns inga signifikanta skillnader mellan städerna vad gäller deltagarnas ålders- och könsfördelning samt deras föräldrars turkiska hemorters storlek (by, småstad, stad). 
Tabell 3. Översikt över de statistiska skillnaderna mellan Stockholm, Rotterdam och Berlin (Mann-Whitney Utest)

\begin{tabular}{|c|c|c|c|c|}
\hline & & $\begin{array}{l}\text { Stockholm } \\
\text { Rotterdam }\end{array}$ & $\begin{array}{l}\text { Stockholm } \\
\text { Berlin }\end{array}$ & Rangordning \\
\hline 1 & Högsta utbildningsnivå bland föräldrar & $\begin{array}{l}\text { Sig. }=, 000 \\
(\mathrm{ES}=, 22)\end{array}$ & $\begin{array}{l}\text { Sig. }=, 000 \\
(\mathrm{ES}=, 52)\end{array}$ & $\mathrm{ST}>\mathrm{RO}>\mathrm{BE}$ \\
\hline \multicolumn{5}{|c|}{ INSTITUTIONELL INTEGRATION } \\
\hline 2 & Medborgarskap i undersökningslandet & Sig. $=, 427$ & $\begin{array}{l}\text { Sig. }=, 004 \\
(\mathrm{ES}=, 18)\end{array}$ & $\mathrm{ST}=\mathrm{RO}>\mathrm{BE}$ \\
\hline 3 & Startåldern för offentlig utbildning & $\begin{array}{l}\text { Sig. }=, 000 \\
(\mathrm{ES}=, 28)\end{array}$ & $\begin{array}{l}\text { Sig. }=, 000 \\
(E S=, 32)\end{array}$ & $\mathrm{ST}<\mathrm{RO}=\mathrm{BE}$ \\
\hline 4 & Högsta utbildningsnivå med examen & Sig. $=, 355$ & $\begin{array}{l}\text { Sig. }=, 000 \\
(\mathrm{ES}=, 32)\end{array}$ & $\mathrm{ST}=\mathrm{RO}>>\mathrm{BE}$ \\
\hline 5 & $\begin{array}{l}\text { Andelen sysselsatt med utbildning, arbete, } \\
\text { praktik mm. }\end{array}$ & $\begin{array}{r}\text { Sig. }=, 009 \\
(\mathrm{ES}=, 15)\end{array}$ & $\begin{array}{l}\text { Sig. }=, 000 \\
(\mathrm{ES}=, 37)\end{array}$ & $\mathrm{ST}>\mathrm{RO}>\mathrm{BE}$ \\
\hline \multicolumn{5}{|c|}{ SOCIAL INTEGRATION/SEGREGATION I: Relationen till majoritetssamhället } \\
\hline 6 & $\begin{array}{lccc}\text { Storleken av vängrupp } & \text { med } \\
\text { majoritetsbakgrund under skoltiden } & \\
\end{array}$ & $\begin{array}{l}\text { Sig. }=, 001 \\
(\mathrm{ES}=, 20)\end{array}$ & $\begin{array}{l}\text { Sig. }=, 000 \\
(E S=, 29)\end{array}$ & $\mathrm{ST}>\mathrm{RO}>\mathrm{BE}$ \\
\hline 7 & $\begin{array}{llll}\begin{array}{l}\text { Storleken av } \\
\text { majoritetsbakgrund nu }\end{array} & \text { vängrupp } & \text { med } \\
\end{array}$ & $\begin{array}{l}\text { Sig. }=, 000 \\
(\mathrm{ES}=, 23)\end{array}$ & $\begin{array}{l}\text { Sig. }=, 000 \\
(\mathrm{ES}=, 37)\end{array}$ & $\mathrm{ST}>\mathrm{RO}>\mathrm{BE}$ \\
\hline 8 & Styrkan av stadstillhörighet & Sig. $=, 112$ & $\begin{array}{l}\text { Sig. }=, 000 \\
(\mathrm{ES}=, 22)\end{array}$ & $\mathrm{ST}=\mathrm{RO}>\mathrm{BE}$ \\
\hline \multicolumn{5}{|c|}{ SOCIAL INTEGRATION/SEGREGATION II: Relationen till den egna etniska gruppen } \\
\hline 9 & $\begin{array}{l}\text { Andelen invånare i bostadsområdet som har } \\
\text { turkisk bakgrund }\end{array}$ & $\begin{array}{l}\text { Sig. }=, 000 \\
(\mathrm{ES}=, 30)\end{array}$ & $\begin{array}{l}\text { Sig. }=, 000 \\
(\mathrm{ES}=, 47)\end{array}$ & $\mathrm{ST}<<\mathrm{RO}<\mathrm{BE}$ \\
\hline 10 & $\begin{array}{l}\text { Andelen närmaste vänner med turkisk } \\
\text { bakgrund under skoltiden }\end{array}$ & $\begin{array}{l}\text { Sig. }=, 000 \\
(\mathrm{ES}=, 23)\end{array}$ & $\begin{array}{l}\text { Sig. }=, 000 \\
(\mathrm{ES}=, 40)\end{array}$ & $\mathrm{ST}<\mathrm{RO}<\mathrm{BE}$ \\
\hline 11 & $\begin{array}{l}\text { Andelen närmaste vänner med turkisk } \\
\text { bakgrund nu }\end{array}$ & $\begin{array}{l}\text { Sig. }=, 001 \\
(\mathrm{ES}=, 20)\end{array}$ & $\begin{array}{l}\text { Sig. }=, 000 \\
(\mathrm{ES}=, 26)\end{array}$ & $\mathrm{ST}<\mathrm{RO}=\mathrm{BE}$ \\
\hline 12 & Andelen partners med turkisk bakgrund & $\begin{array}{l}\text { Sig. }=, 000 \\
(\mathrm{ES}=, 36)\end{array}$ & $\begin{array}{l}\text { Sig. }=, 000 \\
(\mathrm{ES}=, 36)\end{array}$ & $\mathrm{ST}<<\mathrm{RO}=\mathrm{BE}$ \\
\hline 13 & Styrkan av turkisk tillhörighet & $\begin{array}{l}\text { Sig. }=, 002 \\
(E S=, 18)\end{array}$ & Sig. $=, 395$ & $\begin{array}{l}\mathrm{ST}<\mathrm{RO} \\
\mathrm{ST}=\mathrm{BE}, \\
\mathrm{BE}=\mathrm{RO}\end{array}$ \\
\hline
\end{tabular}

Notis: ES=effektstorlek, $>/<$ signifikant skillnad med liten effektstorlek $(\mathrm{ES}<0,3)$,

$>><<$ signifikant skillnad med medelstor effektstorlek $(0,3 \leq \mathrm{ES}),=$ ingen signifikant skillnad

Tabell 3 ger en överblick över huruvida och i vilken utsträckning gruppen i Stockholm skiljer sig från motsvarande grupper i Rotterdam respektive Berlin vad gäller olika integrationsvariabler. Signifikansvärdena från Mann-Whitney U-testet i de mellersta kolumnerna indikerar huruvida det fanns statistiskt signifikanta skillnader mellan grupperna i parvisa jämförelser. Förutom variablerna på raderna 2, 4, 8 och 13 var de flesta skillnaderna mellan Stockholm och de andra två städerna signifikanta på 1-procentsnivån. Effektstorleken i samma kolumner anger vidare hur stor skillnaden var i de fall där det hittades en signifikant skillnad. Sista kolumnen rangordnar städerna enligt uppgifterna i de mellersta kolumnerna och i motsvarande kategorier i Tabell 2. Stockholmsgruppens skillnader i jämförelse med gruppen i Rotterdam tenderade att vara små medan jämförelsen med Berlin uppvisade en blandning av små och medelstora skillnader enligt effektstorlekarna.

När den institutionella integrationen undersöktes enligt fyra olika variabler (se raderna 3-6 i tabeller $2 \& 3$ ) blev den samlade bilden att andragenerationens turkar i Berlin hade den tydligt lägsta graden av integration medan gruppen i Stockholm uppvisade en något högre grad än Rotterdam i två av fyra variabler. Den institutionella integrationen "förankrar" talaren i samhällets olika institutionella kontexter som utbildningsinstitutionerna och arbetsmarknaden. Den fortsatta inkluderingen i dessa kontexter förmedlar å ena sidan till talaren att samhället ger henne/honom värdefulla utvecklingsmöjligheter, vilket ökar den integrativa motivationen som 
är relevant för andraspråksinlärningen (Gardner \& Lambert, 1972). ^̊ andra sidan skapar institutionell integration även formella och informella möjligheter att utveckla och använda majoritetsspråket. Därför kan man förvänta sig att den högre institutionella integrationen i Stockholm skulle leda till högre nivåer av andraspråksbehärskning där. Eftersom starten i den offentliga utbildningen kan överlappa starten av andraspråksinlärningen, i synnerhet i lägre åldrar, kan denna variabel åtminstone delvis betraktas som ett surrogat för startåldern för andraspråksinlärningen. Eftersom tidigare forskning visat att lägre startåldrar har en positiv inverkan på andraspråksbehärskningen (Dörnyei \& Skehan, 2003) men en negativ inverkan på förstaspråksbehärskningen (Montrul, 2016, s. 113) skulle vi utifrån denna variabel kunna förvänta oss högre nivåer av andraspråksbehärskning och lägre nivåer av förstaspråksbehärskning i Stockholm.

Raderna 6-12 i tabellerna 2 och 3 sammanfattar olika aspekter av deltagarnas sociala integration i (alternativt segregation från) majoritetssamhället utifrån deras relationer med och tillhörighetskänsla till personer med majoritetsbakgrund (raderna 6-8) och personer från den egna etniska gruppen (raderna 9-13). Vänskapsrelationerna med majoritetssamhället var tydligt starkast i Stockholm och svagast i Berlin med Rotterdam i positionen däremellan (raderna 6-7). Eftersom vänskapsrelationer utgör en avgörande kontext för informell språkinlärning och -användning skulle vi kunna förvänta oss att gruppen i Stockholm skulle rapportera högre nivåer av andraspråksbehärskning. För att mäta tillhörighetskänslan till den omgivande kontexten används här stadstillhörighet ( $\mathrm{rad} 8)$ istället för tillhörighet till majoritetsgruppen. Detta beror dels på att styrkan av stadstillhörighet har visat sig vara mer känslig för skillnader i integrationskontexten i en vidare jämförelse bland TIES-städerna (Aktürk-Drake, 2017). Vidare finns det metodologiska problem med hur frågan om nationell tillhörighet uppfattas i den tyska kontexten där medborgarskap i undersökningslandet inte varit en självklarhet (se rad 2 i Tabell 2). Stadstillhörigheten var betydligt svagare i Berlin och starkast i Stockholm, men skillnaden mellan Stockholm och Rotterdam var inte signifikant. Eftersom tidigare forskning (Gardner \& Lambert, 1972; Spolsky, 1989) visat att starkare tillhörighetskänslor gentemot det omgivande samhället har en positiv påverkan på andraspråksbehärskningen genom attityder och motivation skulle vi kunna förvänta oss högsta nivån av andraspråksbehärskning i Stockholm och lägsta nivån i Berlin.

Vad gäller relationen till den egna gruppen framstår integrationskontexten i Berlin som en turkisk enklav där en tydlig majoritet av grannarna, närmaste vännerna och partners består av turkar (se raderna 9-12 i Tabell 2). Gruppen i Rotterdam uppvisar ett liknande mönster med mycket täta relationer med andra turkar men här dominerades bostadsområdet inte av turkar i samma utsträckning, varför kontexten inte riktigt kan beskrivas som en turkisk enklav. Gruppen i Stockholm avviker tydligt från dessa två mönster och framstår istället som multietniskt präglad där umgänget med turkar inte dominerar de sociala relationerna förutom i partnervalet, utan snarare utgör en viktig beståndsdel i ett multietniskt umgänge med större balans mellan personer med majoritetsbakgrund, turkisk bakgrund och annan utländsk bakgrund. Den turkiska tillhörigheten var minst stark i Stockholm med en signifikant skillnad mot Rotterdam men skillnaden mot Berlin visade sig inte vara signifikant (se rad $13 \mathrm{i}$ Tabellerna 2 och 3). Rotterdam uppvisade den starkaste turkiska tillhörigheten men utan att vara signifikant högre än Berlin. Eftersom tidigare forskning (Hyltenstam m.fl., 1999, s. 54-62, 82-88; Pauwels, 2016, s. 101-113) visat att social och kulturell segregation från majoritetssamhället och minoritetsgruppens storlek har en gynnsam effekt på arvspråksbevarande skulle vi kunna förvänta oss lägre nivåer av turkiskbehärskning i Stockholm där den turkiska gruppen är både mindre och mindre segregerad. Här lär såväl attityder, som återspeglas $\mathrm{i}$ graden av turkisk tillhörighet, som de faktiska informella möjligheterna till arvspråksutveckling, som avspeglas i styrkan på relationerna med andra 
turkar som potentiella samtalspartners i turkiska, innebära fördelar i Berlins enklavartade kontext och nackdelar i den motsatta multietniska kontexten i Stockholm.

Den samlade bedömningen av samtliga variabler relaterade till både institutionell och social integration utifrån tabellerna 2 och 3 blir således att gruppen i Stockholm uppvisar den högsta graden av integration och gruppen i Berlin verkar vara den minst integrerade medan Rotterdam intar en mellanposition. Därmed kan detta mönster sägas i princip följa rangordningen av länderna enligt inkluderingsgraden av deras integrationskontexter som diskuterades tidigare utifrån resultat från flera andra internationella undersökningar (se rad 10 i Tabell 1). Stockholm och Berlin framträder följaktligen som integrationsmässiga motpoler där Stockholm kombinerar en hög grad av inkludering med en liten och utspridd turkisk grupp medan Berlin uppvisar en låg grad av inkludering med en stor och koncentrerad turkisk grupp. Rotterdam intar återigen mittenpositionen enligt dessa två dimensioner.

\section{Tal- och skrivfärdigheter i bägge språken i Stockholm}

Resultaten för språkfärdigheterna på gruppnivå i Tabell 4 visar att närmare nio av tio deltagare i Stockholm bedömde sin färdighetsnivå i svenska som mycket hög (antingen utmärkt eller mycket bra) medan ungefär hälften av deltagarna gjorde samma bedömning för sina turkiskfärdigheter.

Tabell 4. Översikt över resultaten gällande färdighetsnivåer på gruppnivå bland andra generationens turkar $\mathrm{i}$ Stockholm (i procentandel)

\begin{tabular}{lllll}
\hline $\begin{array}{l}\text { Färdighetsnivå } \\
\text { (numeriskt värde) }\end{array}$ & $\begin{array}{l}\text { Talfärdighet } \\
\text { i svenska }\end{array}$ & $\begin{array}{l}\text { Skrivfärdighet } \\
\text { i svenska }\end{array}$ & $\begin{array}{l}\text { Talfärdighet } \\
\text { i turkiska }\end{array}$ & $\begin{array}{l}\text { Skrivfärdighet } \\
\text { i turkiska }\end{array}$ \\
\hline Utmärkt (6) & 67,7 & 74,4 & 26,3 & 24,1 \\
\hline Mycket bra (5) & 21,8 & 14,3 & 30,8 & 21,8 \\
\hline Bra (4) & 10,5 & 11,3 & 36,1 & 37,6 \\
\hline Inte så bra (3) & 0 & 0 & 5,2 & 9 \\
\hline Dålig (2) & 0 & 0 & 0,8 & 6 \\
\hline Inte bra alls (1) & 0 & 0 & 0,8 & 1,5 \\
\hline
\end{tabular}

Uppgifterna på individnivå i de första två kolumnerna av Tabell 5 bygger på de 6 färdighetsnivåerna $\mathrm{i}$ första kolumnen av Tabell 4. Om en talare exempelvis angav färdighetsnivån utmärkt (6) för sitt L2 och bra (4) för sitt L1 blir den numeriska nivåskillnaden 2 (6-4=2). I de fall där färdigheterna angavs som högre i L1 jämfört med L2 har nivåskillnaden ett negativt värde. Tabell 5 bekräftar att det finns en påtaglig skillnad i den självuppskattade behärskningen av språken. En tydlig majoritet kring 60 procent angav att de var bättre på att både tala och skriva sitt andraspråk svenska än sitt förstaspråk turkiska. 38,3 procent angav att de hade balanserade talfärdigheter (dvs. ingen skillnad mellan språken) medan bara 28,6 procent angav att de hade balanserade skrivfärdigheter. Vidare visade det sig att andelen talare som var helt balanserade, dvs. var balanserade i bägge färdigheterna samtidigt, var 24,1 procent. Bland dessa talare var 75 procent balanserade på nivån "utmärkt" medan 12,5 procent vardera var balanserade på nivåerna "mycket bra" respektive "bra".

Tabell 5. Översikt över resultaten gällande språklig balans på individnivå bland andragenerationens turkar i Stockholm (i procentandel)

\begin{tabular}{ll}
\hline Nivåskillnad mellan L2 \& L1 i talfärdighet & Nivåskillnad mellan L2 \& L1 i skrivfärdighet \\
\hline 3 eller fler nivåer: 3,8 & 3 eller fler nivåer: 11,2 \\
\hline 1 eller 2 nivåer: 54,1 & 1 eller 2 nivåer: 55,6 \\
\hline Ingen skillnad: 38,3 & Ingen skillnad: 28,6 \\
\hline -1 eller -2 nivåer: 3,8 & -1 eller -2 nivåer: 4,6 \\
\hline -3 eller fler nivåer: 0 & -3 eller fler nivåer: 0 \\
\hline
\end{tabular}

Notis: Positiva värden innebär dominans i L2 medan negativa värden innebär dominans i L1 
Tabell 6 sammanfattar resultatet av de statistiska testerna avseende skillnader mellan språken och inom vartdera språket hos individuella talare. Som p-värdena i näst sista kolumnen visar fanns det signifikanta skillnader på 1-procentsnivån i tre av de fyra jämförelserna. Z-värdet användes för att beräkna effektstorleken enligt formeln som redovisades i analysavsnittet. Enligt mellersta kolumnen hade de signifikanta skillnaderna mellan språken i en och samma färdighet en stor effektstorlek (se raderna 1 och 2) medan skillnaden mellan de två färdigheterna i turkiska var medelstor (se rad 4). De två första raderna bekräftar ännu en gång att det finns stora skillnader mellan de två språken inom samma färdigheter. De två sista raderna visar vidare att det inte fanns någon signifikant skillnad mellan färdigheterna inom svenskan där mediansvaret för bägge färdigheterna var "utmärkt". Däremot fanns det en medelstor skillnad inom turkiskan som även återspeglas $\mathrm{i}$ att mediansvaret för talfärdigheten ligger en nivå över mediansvaret för skrivfärdigheten.

Tabell 6. Skillnader mellan färdigheter i de två språken enligt Wilcoxon Signed Rank-test (N=133)

\begin{tabular}{lllll}
\hline & $\mathbf{Z}$ & Effektstorlek & $\mathbf{p}$ & Mediansvar \\
\hline Talfärdigheter i turkiska och svenska & $-7,342$ &, 64 &, 000 & \\
\hline Skrivfärdigheter i turkiska och svenska & $-7,976$ &, 69 &, 000 & \\
\hline \hline Tal- och skrivfärdigheter i svenska & $-1,547$ &, 13 &, 122 & $\begin{array}{l}\text { Talfärdighet: Utmärkt } \\
\text { Skrivfärdighet: Utmärkt }\end{array}$ \\
\hline Tal- och skrivfärdigheter i turkiska & $-4,445$ &, 39 &, 000 & $\begin{array}{l}\text { Talfärdighet: Mycket bra } \\
\text { Skrivfärdighet: Bra }\end{array}$ \\
\hline
\end{tabular}

Eftersom skrivfärdigheten tydligt hänger ihop med språkstödet i skolan kan de betydligt lägre skrivfärdighetsnivåerna i turkiska samt glappet mellan dem och talfärdigheterna i turkiskan i Tabell 6 utan vidare tolkas som ett resultat av den bristfälliga implementeringen av modersmålsundervisningen i svenska skolor. Därmed kan det konstateras att andragenerationens turkar i Sverige haft en tvåspråkig utveckling som å ena sidan lett till en färdighetsmässigt jämlik och mycket hög behärskningsnivå i andraspråket svenska och å andra sidan till en färdighetsmässigt ojämlik behärskning i förstaspråket turkiska, som dessutom är på en tydligt lägre nivå jämfört med svenskan. Tillsammans med uppgifterna att bara 38,3 respektive 28,6 procent av andragenerationens turkar rapporterade att de var balanserade i sina tal- och skrivfärdigheter samt att endast 24 procent var helt balanserade i samtliga fyra färdigheter visar de samlade resultaten med all tydlighet att målet balanserad tvåspråkighet inte uppnåtts i Stockholm.

\section{Jämförelser mellan Stockholm och de andra två västeuropeiska städerna}

Låt oss nu jämföra dessa resultat från Stockholm med de andra två städerna utifrån vad vi vet om dessa integrationskontexter för andragenerationens turkar. Figurerna 1 och 2 sammanfattar deltagarnas självuppskattade talfärdigheter i andraspråket respektive förstaspråket turkiska i samtliga tre städer medan Tabell 7 sammanfattar resultaten från den statistiska undersökningen om skillnaderna mellan städerna. 
Figur 1. Självuppskattade talfärdigheter på gruppnivå i respektive andraspråk i tre västeuropeiska städer

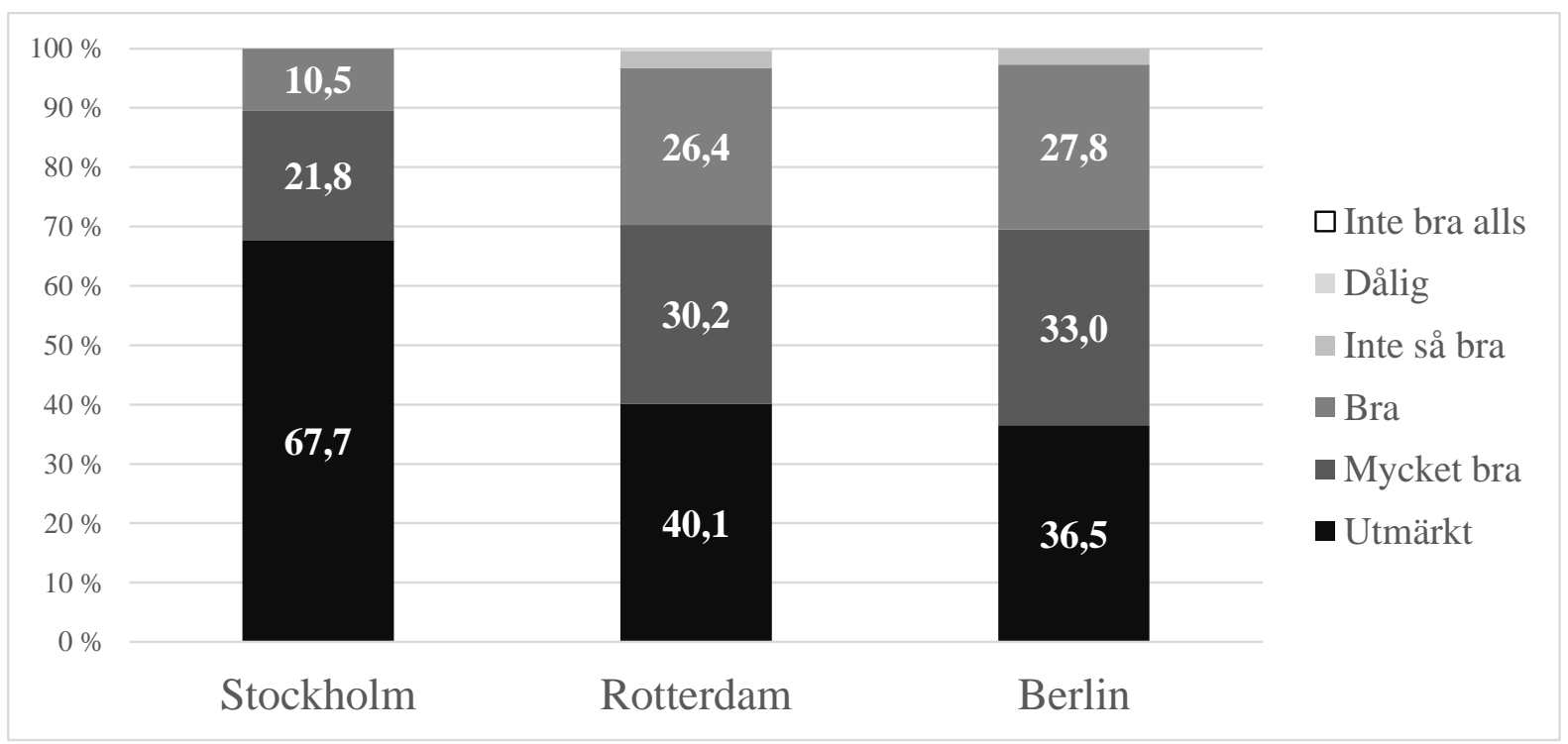

Figur 2. Självuppskattade talfärdigheter på gruppnivå i förstaspråket turkiska i tre västeuropeiska städer

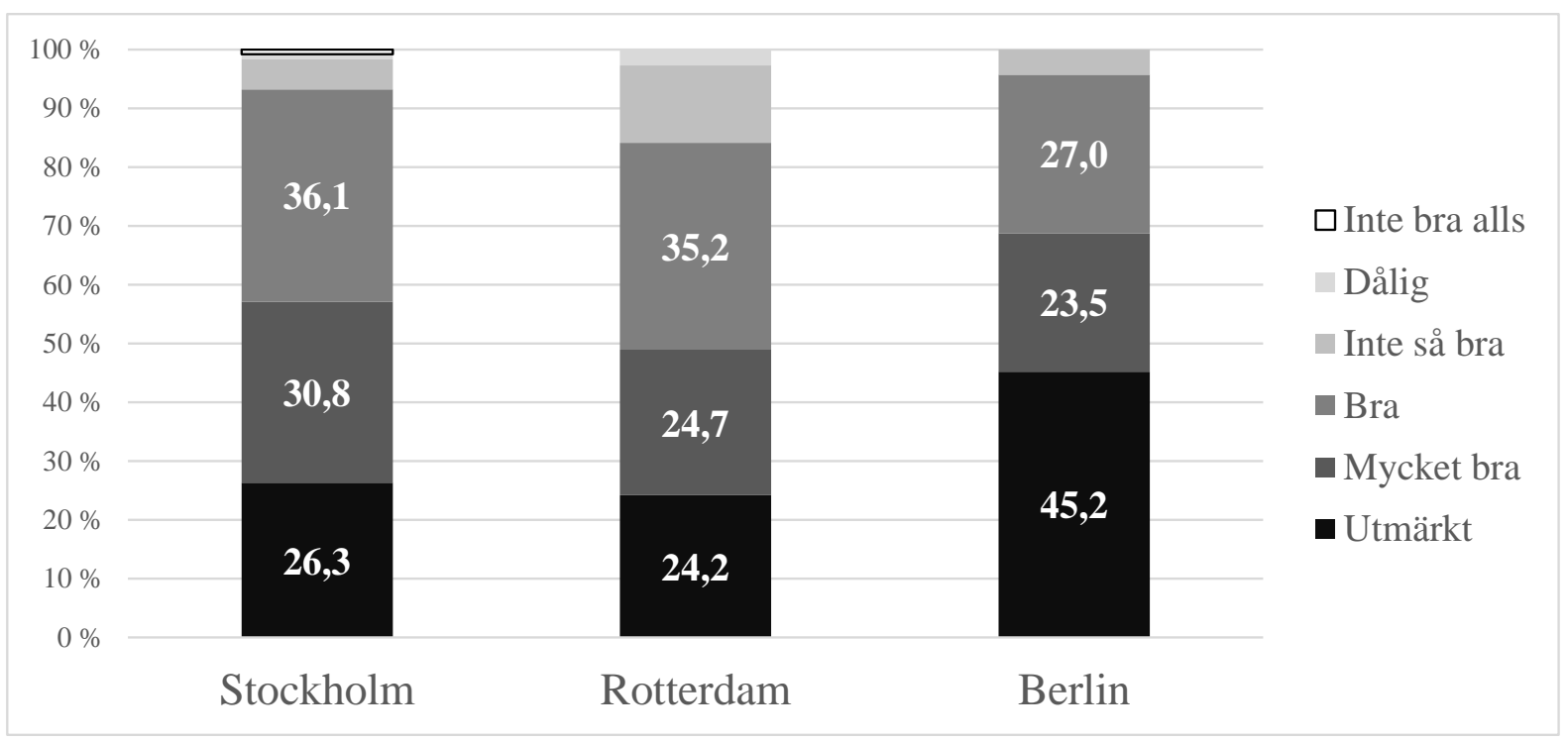

Tabell 7. Statistiska skillnader mellan Stockholm och de andra städerna avseende självuppskattade talfärdigheter (Mann-Whitney U-test)

\begin{tabular}{|c|c|c|c|c|}
\hline & $\begin{array}{l}\text { Stockholm-Rotterdam } \\
(\mathrm{N}=315)\end{array}$ & $\begin{array}{l}\text { Stockholm-Berlin } \\
(\mathrm{N}=\mathbf{2 4 8})\end{array}$ & $\begin{array}{l}\text { Rotterdam-Berlin } \\
(\mathrm{N}=297)\end{array}$ & $\begin{array}{l}\text { Rangordning } \\
\text { mellan städerna }\end{array}$ \\
\hline $\begin{array}{l}\text { Talfärdighet } \\
\text { i andraspråket }\end{array}$ & $\begin{array}{l}\mathrm{Z}=-5,176 \\
\text { Sig. }=, 000 \\
\text { Effektstorlek=,29 }\end{array}$ & $\begin{array}{l}Z=-5,174 \\
\text { Sig. }=, 000 \\
\text { Effektstorlek=,33 }\end{array}$ & $\begin{array}{l}Z=-, 421 \\
\text { Sig.=, } 674\end{array}$ & $\mathrm{ST}>\mathrm{RO}=\mathrm{BE}$ \\
\hline $\begin{array}{l}\text { Talfärdighet } \\
\text { i förstaspråket } \\
\text { turkiska }\end{array}$ & $\begin{array}{l}Z=-1,676 \\
\text { Sig.=,094 }\end{array}$ & $\begin{array}{l}Z=-2,804 \\
\text { Sig.=,005 } \\
\text { Effektstorlek=,18 }\end{array}$ & $\begin{array}{l}\mathrm{Z}=-4,269 \\
\text { Sig. }=, 000 \\
\text { Effektstorlek=,25 }\end{array}$ & $\mathrm{ST}=\mathrm{RO}<\mathrm{BE}$ \\
\hline
\end{tabular}

Notis: = ingen signifikant skillnad, $>/<$ signifikant skillnad med liten effektstorlek $(\mathrm{ES}<0,3)$,

$>>/<<$ signifikant skillnad med medelstor effektstorlek $(0,3 \leq \mathrm{ES}<0,5)$ 
Resultaten i Tabell 7 visar att det fanns signifikanta skillnader på 1-procentsnivån mellan grupperna i Stockholm och Berlin i talfärdigheterna i bägge språken (se mellersta kolumnen) där skillnaden var liten i förstaspråket och medelstor i andraspråket. Jämförelsen mellan Stockholm och Rotterdam uppvisade bara en signifikant skillnad med en liten effektstorlek i talfärdigheterna i andraspråket. Mellan Rotterdam och Berlin fanns det däremot en signifikant skillnad med liten effektstorlek i talfärdigheten i förstaspråket. Sista kolumnen i Tabell 7 presenterar en sammanfattande rangordning utifrån dessa jämförelser och färdighetsnivåerna $i$ Figurerna 1 och 2. Enligt dessa uppgifter uppskattas färdighetsnivån i andraspråket som signifikant högre i Stockholm jämfört med de andra två städerna (med effektstorlekar kring gränsen mellan liten och medelstor). Det är framför allt i svarskategorin "utmärkt" som Stockholm överträffar de andra städerna. Vad gäller förstaspråksfärdigheterna är det däremot Berlin som visar lite högre nivåer för talfärdigheterna medan gruppen i Stockholm presterar på en statistiskt liknande nivå som gruppen i Rotterdam trots något högre förekomst av de tre högsta svarskategorierna i Stockholm. Dessa resultat visar tydligt att Stockholms och Berlins status som integrationsmässiga motpoler även återspeglas i talfärdigheterna. Den starkt inkluderande och multietniska kontexten i Stockholm leder nämligen till avsevärt högre talfärdighetsnivåer i andraspråket men även till lite lägre färdighetsnivåer i förstaspråket jämfört med den svagt inkluderande och enklavartade kontexten i Berlin. Resultaten angående skrivfärdigheterna var snarlika resultaten för talfärdigheterna och redovisas här inte av utrymmesskäl. De kommer istället att vägas in i olika balansmått som diskuteras härnäst.

Figurerna 3 och 4 samt Tabell 8 illustrerar skillnaderna mellan språken inom en och samma färdighet på individnivå. Ingen skillnad tolkas som balans medan en skillnad på en eller två nivåer (av totalt sex) betraktas som "svag dominans" och en skillnad på tre eller fler nivåer som "stark dominans". Resultaten i figurerna 3 och 4 visar å ena sidan att gruppen i Stockholm med drygt 60 procent har den högsta andelen andraspråksdominanta (L2-dominanta) individer när andelen svagt och starkt L2-dominanta räknas ihop. Högsta andelen L1-dominanta individer finns istället med ungefär 30 procent i Berlin. Vad gäller balanserade tvåspråkiga är andelen lägst i Stockholm med bara 38,3 respektive 28,6 procent som anger samma tal- och skrivfärdighetsnivå i bägge språken. Berlin och Rotterdam har med knappt 50 procent vardera ungefär samma andel balanserade tvåspråkiga vad gäller talfärdigheter medan Rotterdam med drygt 40 procent har den högsta andelen balanserade tvåspråkiga vad gäller skrivfärdigheter.

Figur 3. Självuppskattade skillnader i talfärdighet mellan andra- och förstaspråket i tre västeuropeiska städer

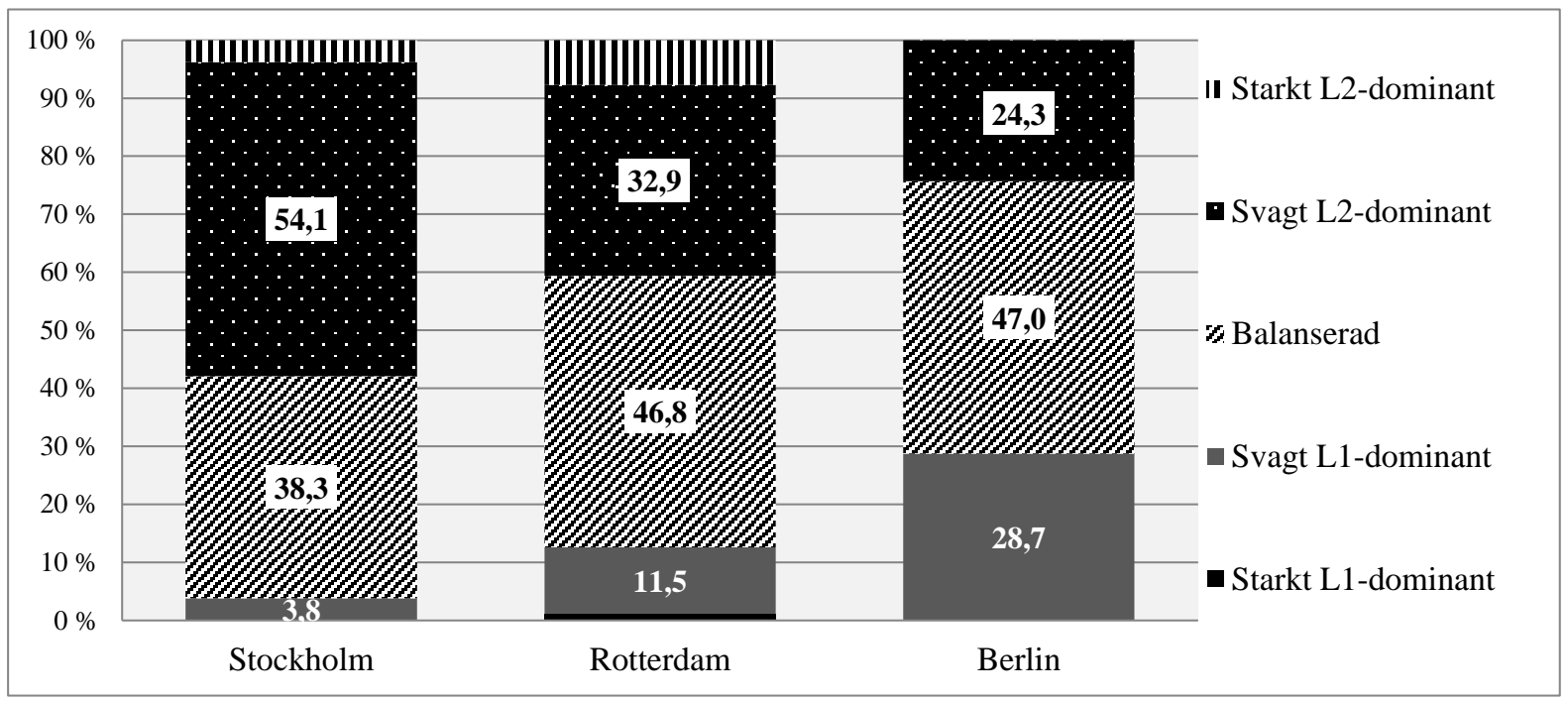


Figur 4. Självuppskattade skillnader i skrivfärdighet mellan andra- och förstaspråket i tre västeuropeiska städer

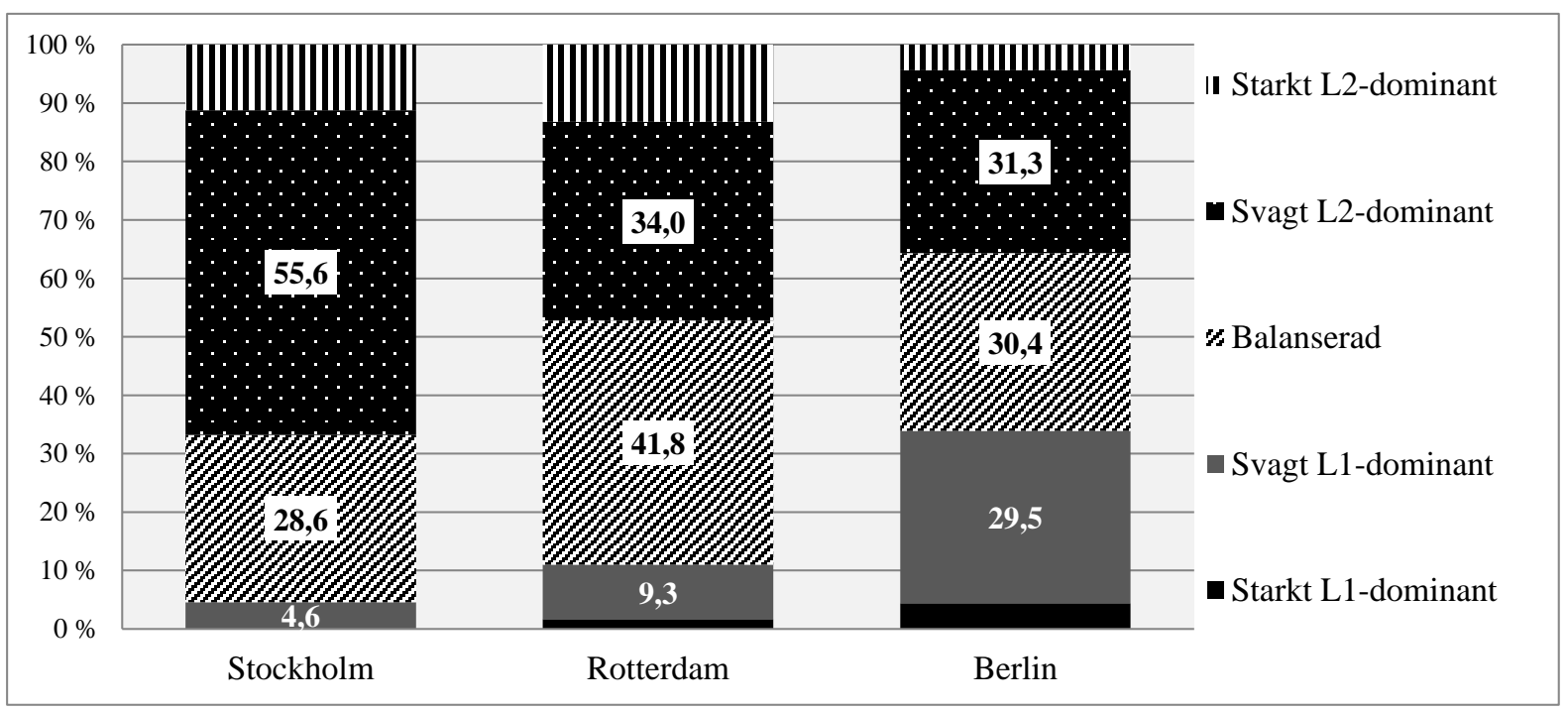

Tabell 8. Statistiska skillnader mellan Stockholm och de andra städerna avseende andraspråksdominans utifrån självuppskattade tal- och skrivfärdigheter i bägge språken (Mann-Whitney U-test)

\begin{tabular}{|c|c|c|c|c|}
\hline & $\begin{array}{l}\text { Stockholm-Rotterdam } \\
(\mathrm{N}=315)\end{array}$ & $\begin{array}{l}\text { Stockholm-Berlin } \\
(\mathrm{N}=\mathbf{2 4 8})\end{array}$ & $\begin{array}{l}\text { Rotterdam-Berlin } \\
\text { (N=297) }\end{array}$ & $\begin{array}{l}\text { Rangordning } \\
\text { mellan städerna }\end{array}$ \\
\hline \multirow[t]{3}{*}{ Talfärdighet } & $\mathrm{Z}=-2,684$ & $Z=-6,627$ & $\mathrm{Z}=-4,139$ & $\mathrm{ST}>\mathrm{RO}>\mathrm{BE}$ \\
\hline & Sig. $=, 007$ & Sig. $=, 000$ & Sig. $=, 000$ & \\
\hline & Effektstorlek=,15 & Effektstorlek $=, 42$ & Effektstorlek=,24 & \\
\hline \multirow[t]{3}{*}{ Skrivfärdighet } & $\mathrm{Z}=-3,041$ & $\mathrm{Z}=-6,209$ & $\mathrm{Z}=-3,936$ & $\mathrm{ST}>\mathrm{RO}>\mathrm{BE}$ \\
\hline & Sig. $=, 002$ & Sig. $=, 000$ & Sig. $=, 000$ & \\
\hline & Effektstorlek=,17 & Effektstorlek=,39 & Effektstorlek $=, 23$ & \\
\hline
\end{tabular}

Notis: = ingen signifikant skillnad, $>/<$ signifikant skillnad med liten effektstorlek $(\mathrm{ES}<0,3)$,

$>>/<<$ signifikant skillnad med medelstor effektstorlek $(0,3 \leq \mathrm{ES}<0,5)$

Resultaten i Tabell 8 visar att samtliga skillnader mellan de tre städerna i bägge färdigheterna är statistiskt signifikanta på 1-procentsnivån. När skillnaderna mellan andra- och förstaspråket i figurerna 3 och 4 samt i Tabell 8 tas i beaktande ur ett L2-dominansperspektiv (med L1dominans som dominans med negativa värden istället) kommer en tydlig rangordning fram där Stockholm följs av Rotterdam som i sin tur följs av Berlin vad gäller bägge färdighetstyperna (se sista kolumnen i Tabell 8). Effektstorleken visar att Stockholms skillnad mot Rotterdam är liten medan skillnaden mot Berlin är medelstor (se kolumner 1 och 2 i Tabell 8). Denna rangordning tyder på ett klart samband mellan integrationskontexten och andraspråksdominans. I Stockholms multietniska och inkluderande integrationskontext tenderar således andragenerationens turkar mot tydlig L2-dominans medan de uppvisar en mer jämlik fördelning mellan L2-dominans, språklig balans och L1-dominans i Berlins enklavartade och mindre inkluderande integrationskontext. Följaktligen blir förekomsten av balanserad tvåspråkighet högst $\mathrm{i}$ den integrationskontext som befinner sig mitt emellan dessa två distinkta typer, nämligen i Rotterdam.

\section{Slutsatser}

Resultaten i denna studie visade att bara en liten andel av barnen till turkiska invandrare rapporterade färdighetsnivåer i sina två språk som kan tolkas som balanserad tvåspråkighet. Det var huvudsakligen färdigheterna i förstaspråket turkiska som inte nådde upp till de mycket höga nivåerna i andraspråket svenska. Eftersom diskrepansen mellan språken var särskilt tydlig i skrivfärdigheterna verkar det sannolikt att den bristfälliga implementeringen av 
modersmålsundervisningen i Sverige delvis ligger bakom detta mönster. Jämförelsen med motsvarande grupper i Rotterdam och Berlin visade att det fanns betydande skillnader mellan integrationskontexterna som bakgrund till deltagarnas tvåspråkiga utveckling. Att den svenska integrationskontexten var mer inkluderande än de nederländska och tyska kontexterna tack vare Sveriges varaktiga mångkulturella integrationspolitik tycks ha bidragit till högre nivåer av andraspråksbehärskning bland andragenerationens turkar i Stockholm. Samtidigt innehöll integrationskontexten i Stockholm en mindre och mindre koncentrerad turkisk grupp än i de andra städerna. Analysen pekade på att en sådan kontext på gruppnivå innebar sämre stöd till förstaspråksutvecklingen och följaktligen även till balanserad tvåspråkighet. Färdighetsnivåerna $\mathrm{i}$ turkiska var nämligen något högre i Berlin men gruppen i Stockholm presterade ändå på samma nivå som gruppen i Rotterdam. Sammanlagt fanns den lägsta andelen tvåspråkiga med balanserade tal- och skrivfärdigheter i Stockholm.

Om de stödåtgärder för förstaspråket hos barn till invandrare som stipulerats i Sveriges mångkulturella språkpolitiska styrdokument från 1970- och 1980-talen hade implementerats på ett effektivt sätt istället för på en minimal nivå hade förstaspråksstödet $i$ viss mån kunnat motverka de negativa effekterna av den turkiska gruppens relativt sett mindre storlek och koncentration i Stockholm. Ett av den svenska integrationskontextens utmärkande drag är att den inte domineras så starkt av några få stora invandrargrupper som i många andra västeuropeiska länder utan snarare består av många olika små eller medelstora grupper som dessutom inte brukar bilda egna etniska enklaver. Även om turkar som en medelstor grupp utgör en av de tio största minoritetsspråksgrupperna i Sverige är gruppen betydligt mindre (och numerärt mindre dominant) i Sverige jämfört med många andra västeuropeiska länder. Om den turkiska gruppens storlek och utspriddhet i Stockholm därmed är en nackdel för andra generationens förstaspråksutveckling kan vi extrapolera att samma nackdel kommer att gälla för ett stort antal invandrargrupper i Sverige som är mindre och mindre koncentrerade än den turkiska gruppen. Ur detta perspektiv är det ytterst viktigt att de mångkulturella språkpolitiska målen gällande förstaspråksstödet efterlevs bättre i Sveriges atomiserade minoritetsspråkslandskap.

Även om målet balanserad tvåspråkighet inte uppnåtts befann sig behärskningsnivåerna på en relativt hög nivå i Sverige. Andelen andragenerationens turkar i Stockholm som rapporterade utmärkta eller mycket goda färdigheter uppgick trots allt till 90 procent i svenska och var kring 50 procent i turkiska. Det bör påpekas här att den svenska integrationskontexten levererat dessa resultat mot en bakgrund av ganska hög grad av integration i samhället för den undersökta gruppen. Detta står i uppenbar kontrast till den nederländska och i synnerhet den tyska integrationskontexten där det viktigaste bidraget till de relativt sett mer balanserade tvåspråkiga profilerna snarare utgjordes av den påtagliga segregationens kombinerade negativa effekter på andraspråket och positiva effekter på förstaspråket. Därför har vi goda skäl att tro att Sveriges mångkulturella integrations- och språkpolitik utgör ett lovande recept för att kombinera en hög grad av integration med höga behärskningsnivåer i bägge språken. Att målet balanserad tvåspråkighet inte uppnåtts $\mathrm{i}$ den undersökta gruppen beror således sannolikt inte på att de politiska målen eller instrumenten varit olämpliga utan snarare på att språkpolitiken varken implementerats på ett effektivt sätt eller vidareutvecklats sedan 1990-talet för att bättre uppfylla målen. 


\section{Referenser}

Abrahamson, N. \& Hyltenstam, K. (2008). The robustness of aptitude effects in nearnative second language acquisition. Studies in Second Language Acquisition, 30:4, 481-509.

Aktürk-Drake, M. (2017). Turkish maintenance and bilingualism among secondgeneration Turks in multicultural Stockholm. I B. Başer \& P. T. Levin (Red.), Migration from Turkey to Sweden: Integration, Belonging and Transnational Community (s. 122-152). London: IB Tauris.

Statistischer Bericht AI5 - hj 2/16 (2017). Einwohnerinnen und Einwohner im Land Berlin am 31. Dezember 2016. Berlin: Amt für Statistik Berlin-Brandenburg.

Beets, G., ter Bekke, S. \& Schoorl, J. (2008). I M. Crul \& L. Heering (Red.), The Position of the Turkish and Moroccan Second Generation in Amsterdam and Rotterdam. The TIES study in the Netherlands (s. 27-48). Amsterdam: Amsterdam University Press.

Bengtsson, B. \& Borevi, K. (2015). Mångfaldens vägskäl - om integrationspolitikens stigberoende. I B. Bengtsson, G. Myrberg \& K. Borevi (Red.), Mångfaldens dilemman. Medborgarskap och integrationspolitik (s. 17-40). Lund: Gleerups.

Bourhis, R. Y., Moïse, L. C., Perreault, S. \& Senécal, S. (1997). Towards an interactive acculturation model: A social psychological approach. International Journal of Psychology, 32, 369-386.

Bylund, E. \& Díaz, M. (2012). The effects of heritage language instruction on first language proficiency. A psycholinguistic perspective. International Journal of Bilingual Education and Bilingualism, 15: 5, 593-609.

Crul, M., Schneider, J. \& Lelie, F. (Red.) 2012: The European Second Generation Compared. Does the Integration Context Matter? Amsterdam: Amsterdam University Press.

Derwing, T. M. (2008). Curriculum issues in teaching pronunciation. I J. G. Hansen Edwards \& M. L. Zampini (Red.), Phonology and Second Language Acquisition (s. 347-370). Amsterdam: John Benjamins.

Dörnyei, Z. \& Skehan, P. (2003). Individual differences in second language learning. I C. J. Doughty \& M. H. Long (Red.), The Handbook of Second Language Acquisition Oxford: Blackwell. 589-630.

Ganuza, N. \& Hedman, C. (under utgivning). The Impact of Mother Tongue Instruction on the Development of Biliteracy: Evidence from Somali-Swedish Bilinguals, Applied Linguistics, amx010, https://doi.org/10.1093/applin/amx010

Gardner, R. \& Lambert, W. E. (1972). Attitudes and Motivation in Second-language Learning. Rowley, MA: Newbury House.

Groenewold, G. \& Lessard-Phillips, L. (2012). Research Methodology. I M. Crul, J. Schneider \& F. Lelie (Red.) The European Second Generation Compared. Does the Integration Context Matter? (s. 39-56) Amsterdam: Amsterdam University Press.

Huddleston, T., Bilgili, Ö., Joki, A.-L. \& Vankova, Z. (2014, 9 december). Migrant Integration Policy Index. Nedladdat från http://www.mipex.eu/key-findings

Hyltenstam, K. \& Milani, T. (2012). Flerspråkighetens sociopolitiska och sociokulturella ramar. I K. Hyltenstam, M. Axelsson \& I. Lindberg (Red.), Flerspråkighet: en forskningsöversikt (s. 17-152). Stockholm: Vetenskapsrådet.

Hyltenstam, K., Stroud, C. \& Svonni, M. (1999). Språkbyte, språkbevarande, revitalisering. Samiskans ställning i svenska Sápmi. I K. Hyltenstam (Red.) Sveriges sju inhemska språk-ett minoritetsspråksperspektiv (s. 41-137). Lund: Studentlitteratur.

Hyltenstam, K. \& Tuomela, V. (1996). Hemspråksundervisningen. I K. Hyltenstam (Red.), Tvåspråkighet med förhinder? Invandrar-och minoritetsundervisning i Sverige (s. 9-109). Lund: Studentlitteratur. 
Lambert, W. E. (1974). Culture and language as factors in learning and education. I F. E. Aboud \& R. D. Meade (Red.) Cultural Factors in Learning and Education (s. 91-122). Bellingham: Western Washington State University.

Lgr 80. Skolöverstyrelsen. (1980). Läroplan för grundskolan. Allmän del: mål och riktlinjer, kursplaner, timplaner. Stockholm: Liber Läromedel/Utbildningsförlag.

Montrul, S. (2016). The Acquisition of Heritage Languages. Cambridge: Cambridge University Press.

Multiculturalism Policy Index (2017, 15 mars). Nedladdat från http://www.queensu.ca/mcp/

Nygren-Junkin, L. (2004). Multilingualism in Göteborg. I G. Extra \& K. Yağmur (Red.), Urban multilingualism in Europe. Immigrant Minority Languages at Home and School (s. 133-162.). Clevedon, UK: Multilingual Matters.

OECD/European Union. (2015). Indicators of Immigrant Integration: Settling In. Paris: OECD Publishing. http://dx.doi.org/10.1787/9789264234024-en

Pauwels, A. (2016). Language Maintenance and Shift. Cambridge: Cambridge University Press.

Prop. 1975:26. Regeringens proposition 1975:26, Riktlinjer för invandrar- och minoritetspolitiken m.m.

Prop. 1975/76:118. Regeringens proposition 1975/76:118. Om hemspråksundervisning för invandrarbarn.

Schmitt, G., \& Oomen-Welke, I. (2005). Teaching the mother tongue in Germany. I W. Tulasiewicz \& A. Adams (Red.), Teaching the mother tongue in a multilingual Europe (s. 137-152). London, UK: Continuum.

Schneider, J. \& Crul, M. 2012: Comparative integration context theory. Participation and belonging in diverse European cities. I M. Crul, J. Schneider \& F. Lelie (Red.) The European Second Generation Compared. Does the Integration Context Matter? (s. 19-38) Amsterdam: Amsterdam University Press.

Skolverket. (2017, 8 maj). Nedladdat från https://www.skolverket.se/skolutveckling/statistik/sok-statistik-om -forskola-skola-och-vuxenutbildning

Statistiska Centralbyrån. (2017, 8 maj). Nedladdat från http://www.statistikdatabasen.scb.se/pxweb/sv/ssd/ START_UF_UF0104/SamElevMSprak/?rxid=816664cb-730b-4624-a565d83298e49e23

SOU 1983:57. Statens offentliga utredningar 1983:57. Olika ursprung - gemenskap i Sverige. Utbildning för språklig och kulturell mångfald.

Spolsky, B. (1989). Conditions for Second Language Learning. Oxford: Oxford University Press.

TNS Opinion \& Social. (2018, 4 september). Special Eurobarometer 469. Integration of Immigrants in the European Union. Survey requested by the European Commission, Directorate-General for Migration and Home Affairs and co-ordinated by the Directorate-General for Communication. Nedladdat från http://data.europa.eu/euodp/en/data/dataset/S2169_88_2_469_ENG

Westin, C. (Red.) (2015). Integration of Descendants of Migrants from Turkey in Stockholm: The TIES Study in Sweden. Amsterdam: Imiscoe Research.

World Values Survey. (2017, 20 september). Nedladdat från http://www.worldvaluessurvey.org/WVSOnline.jsp

Yağmur, K. (2016). Intergenerational Language Use and Acculturation of Turkish Speakers in Four Immigration Contexts. Frankfurt am Main: Peter Lang. 


\footnotetext{
${ }^{1}$ Enligt detta index ingår i stödet för tvåspråkighet såväl tvåspråkig utbildning som modersmålsundervisning på minoritetsspråk.

2 Ämnet kallades hemspråksundervisning fram till 1997.

${ }^{3}$ Här redovisas siffor för 1990-talet därför att studiens deltagare fortfarande gick i skolan då och därför att de äldsta tillgängliga uppgifterna gäller den här perioden.

${ }^{4}$ Enligt personlig kommunikation med Skolverket och Statistiska Centralbyrån

${ }^{5}$ Med arvspråk menas här förstaspråk (i bemärkelsen kronologiskt först inlärda språk) som är minoritetsspråk i den omgivande kontexten.
} 